\title{
The effects of premedication drugs on the lower oesophageal high pressure zone and reflux status of Rhesus monkeys and man
}

\author{
A. W. HALL, A. R. MOOSSA ${ }^{1}$, JOHN CLARK, G. R. COOLEY, AND \\ D. B. SKINNER
}

From the University of Chicago, the Pritzker School of Medicine, the Department of Surgery

SUMMARY Thirty-five human volunteers and eight Rhesus monkeys were studied with standard gastrooesophageal manometric techniques and their reflux status was evaluated with a pH probe placed in the lower oesophagus. Morphine sulphate, pethidine hydrochloride, or diazepam was given intravenously until drowsiness was induced.The manometric and $\mathrm{pH}$ studies were repeated. All three drugs decreased the lower oesophageal high pressure zone and increased the probability of reflux in both monkeys and man. These findings are relevant in the preparation of patients for surgery since gastrooesophageal reflux and pulmonary aspiration may be a problem in the pre- and postoperative phases.

The mechanism of gastrooesophageal competence remains a controversial subject. A statistical association has been demonstrated between the intraluminal high pressure zone (HPZ) at the cardia and gastrooesophageal reflux (Winans and Harris, 1967; Thurer, DeMeester, and Johnson, 1974). Many hormones and drugs have been shown to affect this high pressure zone, but no concomitant change in reflux status has been reported (Glanville and Walls, 1972; Moossa, Cooley, and Skinner, 1973).

Pulmonary aspiration and secondary pneumonitis have resulted from gastrooesophageal reflux, and have been frequent postoperative problems. It was decided to study the effects of three common premedicating and postoperative drugs, namely, morphine sulphate, pethidine hydrochloride, and diazepam, on the high pressure zone and reflux status of Rhesus monkeys and man. The effects of atropine have already been extensively investigated with somewhat conflicting results (Bettarello, Tuttle, and Grossman, 1960; Skinner and Camp, 1968).

\section{Material and Method}

Thirty-five fasting human volunteers and eight fasting

${ }^{1}$ Please direct all correspondence to Dr A. R. Moossa, The Department of Surgery, The University of Chicago Hospitals, 950 East 59 th Street, Chicago, Illinois 60637

Received for publication 10 February 1975.
Rhesus monkeys were studied. Only two of the volunteers had symptoms of gastrooesophageal refluxand one of them was subsequently operated upon and a Hill posterior gastropexy corrected the reflux.

\section{MANOMETRIC STUDIES}

Oesophageal motility was studied by a standard manometric technique. The catheter assembly consisted of three Tygon tubes (internal diameter $0.85 \mathrm{~mm}$ ) bonded together with tetrahydrofuran into a single structure. Pressures were recorded via end holes $5 \mathrm{~cm}$ apart. Throughout the entire recording period all three catheters were continously perfused with physiological saline at the rate of $0.123 \mathrm{ml}$ per minute using a Harvard constant infusion pump. Each tube was connected to a Statham P23 DB transducer which was linked through an amplification system to a Brush direct writing multichannel recorder. Over the course of the experiments calibration was intermittently checked against a mercury manometer to exclude baseline wander and alterations in sensitivity of the equipment.

The catheter was passed via the nose until all three recording tips lay within the stomach. It was withdrawn at half-centimetre intervals until the pressure recording and the response to swallowing showed that all three orifices lay within the body of the oesophagus. The procedure was repeated to give six values for the high pressure zone. 
The high pressure zone in man was measured as the difference between the end expiratory intragastric pressure and the mean peak pressure in the lower oesophagus. In monkeys, the mean intragastric value was subtracted from the mean of the peak lower oesophageal pressure. Fluctuations in the lower oesophageal tracings as a result of swallowing were excluded in the calculation of these mean pressures.

\section{MEASUREMENT OF REFLUX}

Gastrooesophageal reflux was measured using a Beckman intestinal pH electrode no. 39042 which was passed via the other nostril until it lay in the lower oesophagus. In human subjects, the tip of the electrode was placed at a point $5 \mathrm{~cm}$ above the upper limit of the high pressure zone as demonstrated by manometry. The resting $\mathrm{pH}$ of the oesophagus was noted and $150 \mathrm{ml}$ of $0 \cdot 1 \mathrm{~N}$ hydrochloric acid was introduced into the stomach. Oesophageal $\mathrm{pH}$ was recorded with the patient lying supine at rest, after deep breathing, coughing, the Valsalva manoeuvre, and the Muller manoeuvre (inhalation against a closed glottis). This gave five $\mathrm{pH}$ readings. The manoeuvres were repeated with the subject lying on his left side, right side, and finally in a $20^{\circ}$ head-down position. In all, $20 \mathrm{pH}$ values were obtained for each subject. Reflux was deemed to occur if, during a procedure, the $\mathrm{pH}$ fell to below 4. By this method, each human subject was given a reflux score between zero (no reflux in any position) and 20 (reflux in all positions).

In the Rhesus monkey a similar $\mathrm{pH}$ electrode was passed until its tip lay at a point $3 \mathrm{~cm}$ proximal to the high pressure zone. Reflux (measured as a drop in $\mathrm{pH}$ below 4) or lack thereof was observed both at rest and after 10 manual abdominal compressions. These two readings were taken in the fasting state and after the instillation of $0 \cdot 1 \mathrm{~N}$ hydrochloric acid, $7 \mathrm{ml} / \mathrm{kg}$, into the stomach. Thus a maximum of four episodes of reflux could be observed in any given animal.

The minimum dose of morphine sulphate, pethidine hydrochloride, or diazepam required to cause drowsiness in the subject or monkey was administered intravenously and complete gastrooesophageal manometry and reflux tests were repeated. In the human subject the dosage of drugs required to cause drowsiness was as follows: morphine sulphate, 7 to $10 \mathrm{mg}$, pethidine hydrochloride 40 to $50 \mathrm{mg}$, diazepam 2.5 to $10 \mathrm{mg}$. The respective figures for the Rhesus monkey were $1 \mathrm{mg}, 5$ to $7 \mathrm{mg}$, and 0.5 to $1 \mathrm{mg}$.

\section{Analysis of Data}

By the above manometric method six values for the high pressure zone were obtained before and after drug administration. The arithmetic mean was derived for each set of figures and this was taken as the pressure existing in the lower oesophagus in that subject or animal. The statistical significance of the changes in pressures in the high pressure zone obtained were assessed using the paired $t$ test. $P$ values of less than 0.02 were taken as being significant.

In man the significance of the change in ratio of refluxers to nonrefluxers was assessed using the $\chi^{2}$ test and an attempt was made to quantify the degree of reflux by using the score out of 20 in each situation. In the monkey such quantitation was impossible and the animals were therefore classed as refluxers (if the $\mathrm{pH}$ fell below 4 at any one of the four occasions) or as nonrefluxers.

\section{Results}

\section{MANOMETRIC STUDIES}

The individual results obtained in man are shown graphically in figures 1 to 3 and those obtained in Rhesus monkeys are shown in figure 4 . The findings

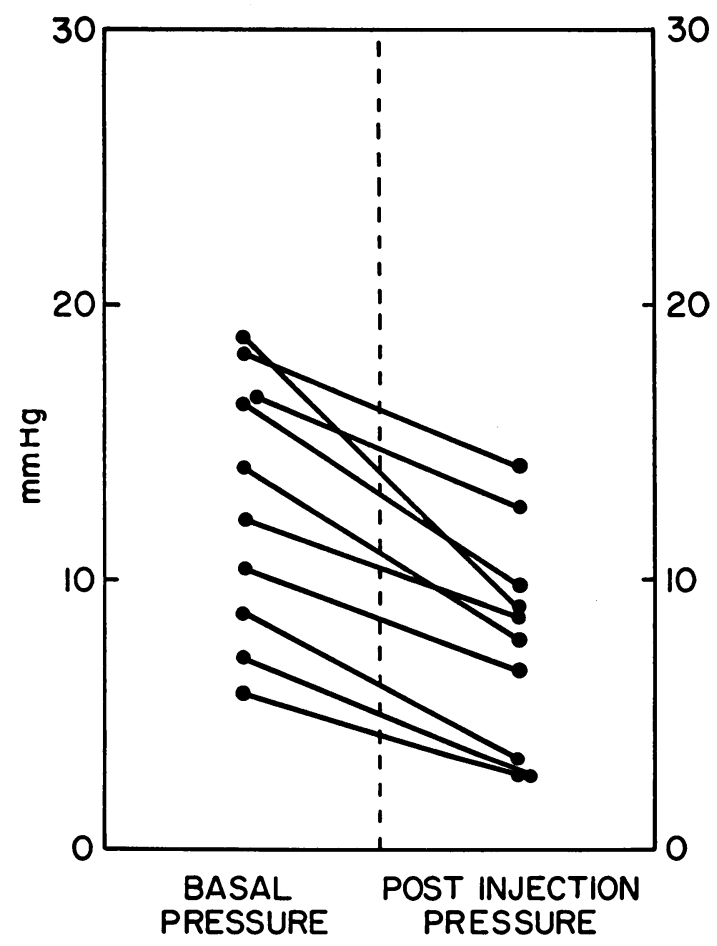

Fig. 1 Response of human lower oesophageal high pressure zone to intravenous morphine in 10 subjects 


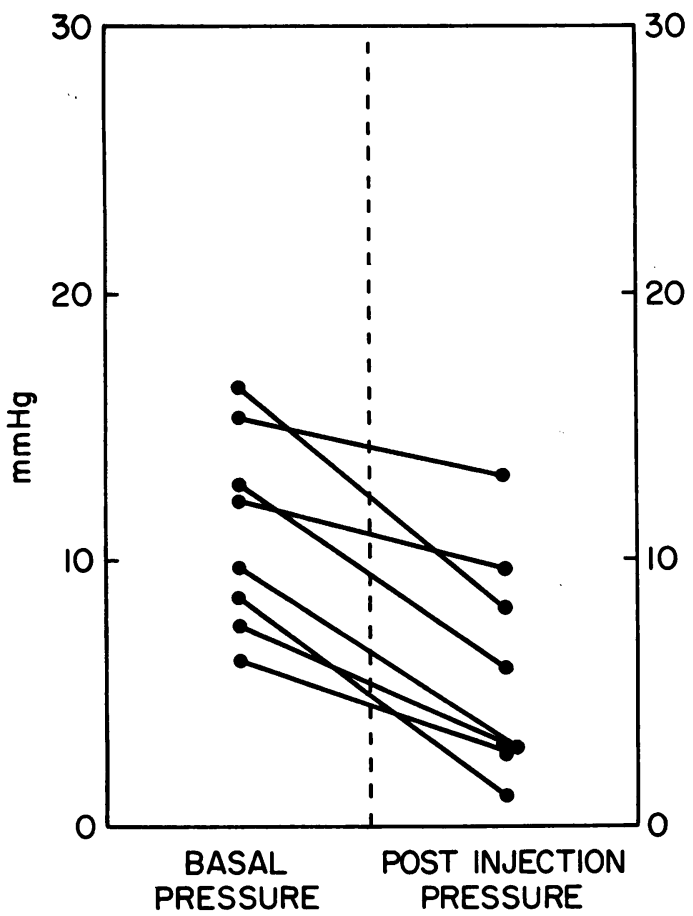

Fig 2

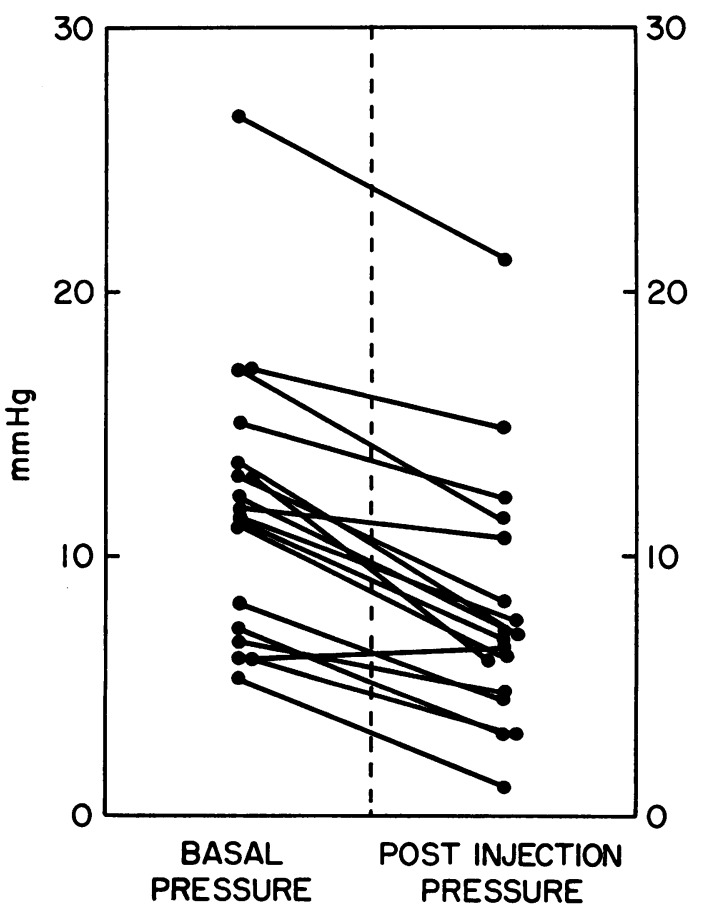

Fig 3

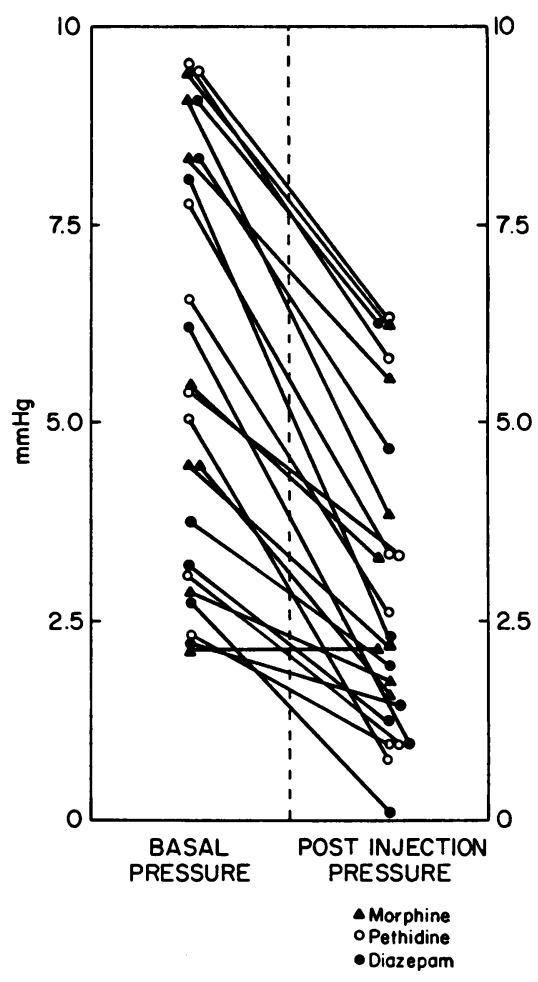

Fig 4

Fig. 2 Response of human lower oesophageal high pressure zone to intravenous pethidine in eight subjects

Fig. 3 Response of human lower oesophageal high pressure zone to intravenous diazepam in 18 subjects

Fig. 4 Response of lower oesophageal high pressure zone to intravenous morphine, pethidine, and diazepam in Rhesus monkey (24 readings) 
were analyzed in two ways. The mean pre- and postinjection pressures were calculated for each group and the significance of the difference between these means was assessed. Next, each postinjection pressure was expressed as a percentage of the preinjection pressure and the significance of this change calculated.

In man, the effects of morphine, pethidine, and diazepam on the manometrically recorded high pressure zone are summarized in table I. All the reductions in values of the high pressure zone except that caused by diazepam (which closely approaches statistical significance, $P=0.025$ ) are statistically significant. When the effects of variation in the preinjection pressures are excluded by expressing the postinjection values as a percentage of the preinjection values, the changes are shown to be highly significant $(P<0.001)$.

Table II summarizes the equivalent results in Rhesus monkeys. Once again the reduction in high pressure zone pressures is significant for all three drugs. In both monkeys and man no significant difference was found between the effects of the three drugs on the high pressure zone.

\section{STANDARD ACID REFLUX TESTS}

We considered the reflux tests of all 35 subjects as one group since no statistical difference could be shown between the effects of the various drugs on the lower oesophageal segment. As one person underwent tests before and after a Hill repair 36 tests were available for analysis.

Fourteen human subjects had significant reflux as measured by a score greater than 2 out of 20 . In these cases the numerical reflux score was increased by injection of these drugs by a mean of 6.35. Twenty-two subjects did not reflux on control testing and 13 of these $(59 \%)$ were induced to do so, the mean postinjection score being $9 \cdot 7$.
A statistical analysis was made of the results of the standard acid reflux tests in man. When the $\chi^{2}$ test was applied to the reflux ratios the change was shown to be significant $(P<0.02)$. The reflux score of each subject was correlated with the pressure in the high pressure zone before and after drug administration. There was no correlation between the preinjection pressure and the preinjection reflux status: $r$ (coefficient of correlation) $=-0.198 ; \mathrm{P}=0.25$. When the postinjection lower oesophageal pressure was correlated with reflux status $r=-0.395$ which is significantly less than zero $(P<0.02)$.

The results of the standard acid reflux test before and after injection of the drugs in Rhesus monkeys were not amenable to statistical analysis. The monkeys were divided into refluxers (one drop of $\mathrm{pH}$ to below 4 out of the four occasions) or nonrefluxers. Table III shows that the relationship between the

\begin{tabular}{clll}
\hline $\begin{array}{l}\text { HPZ Pressure } \\
(\mathrm{mm} \mathrm{Hg})\end{array}$ & $\begin{array}{l}\text { No. of } \\
\text { Readings }\end{array}$ & $\begin{array}{l}\text { No. with } \\
\text { Reflux }\end{array}$ & $\begin{array}{l}\text { Percentage } \\
\text { Reflux }\end{array}$ \\
\hline$>6.5$ & 10 & 1 & 10 \\
$5.0-6.49$ & 10 & 6 & 60 \\
$<5.0$ & 28 & 28 & 100 \\
\hline
\end{tabular}

Table III Relationship between HPZ pressure and reflux status in monkeys

high pressure zone pressure and reflux status depends entirely on the numerical value of the high pressure zone pressure. If this exceeds $6.5 \mathrm{~mm} \mathrm{Hg}$ only $10 \%$ of the reflux tests will be positive. With a value less than $5 \mathrm{~mm} \mathrm{Hg}$ the monkeys will reflux on $100 \%$ of all the occasions. A previously nonrefluxing monkey can be induced to reflux if the drug lowers the pressure in the high pressure zone to this level.

\begin{tabular}{|c|c|c|c|c|c|c|c|}
\hline \multirow{2}{*}{ Drug } & \multicolumn{4}{|c|}{ HPZ Pressure $(\mathrm{mm} \mathrm{Hg}) \pm 1 S E M$} & \multirow{2}{*}{$\begin{array}{l}\text { Postinjection } \mathrm{HPZ} \text { as } \\
\text { Percentage of Preinjection } \\
\text { Value } \pm 1 \text { SEM }\end{array}$} & \multirow{2}{*}{$\mathbf{t}$} & \multirow{2}{*}{$\mathbf{P}$} \\
\hline & Before Injection & After Injection & $\mathbf{t}$ & $\mathbf{P}$ & & & \\
\hline $\begin{array}{l}\text { Morphine } \\
\text { Pethidine } \\
\text { Diazepam }\end{array}$ & $\begin{array}{l}12.89 \pm 1.45 \\
11.16 \pm 1.302 \\
11.81 \pm 1.22\end{array}$ & $\begin{array}{l}7 \cdot 74 \pm 1 \cdot 25 \\
5 \cdot 87 \pm 1.49 \\
7.95 \pm 1 \cdot 14\end{array}$ & $\begin{array}{l}2 \cdot 69 \\
2 \cdot 67 \\
2 \cdot 31\end{array}$ & $\begin{array}{r}<0.02 \\
<0.02 \\
0.025\end{array}$ & $\begin{array}{l}57 \cdot 7 \pm 4 \cdot 65 \\
48 \cdot 39 \pm 8 \cdot 53 \\
64 \cdot 58 \pm 4 \cdot 76\end{array}$ & $\begin{array}{l}9 \cdot 094 \\
6 \cdot 05 \\
7 \cdot 44\end{array}$ & $\begin{array}{l}<0.001 \\
<0.001 \\
<0.001\end{array}$ \\
\hline
\end{tabular}

Table I Effect of morphine, pethidine, and diazepam on the lower oesophageal high pressure zone in man

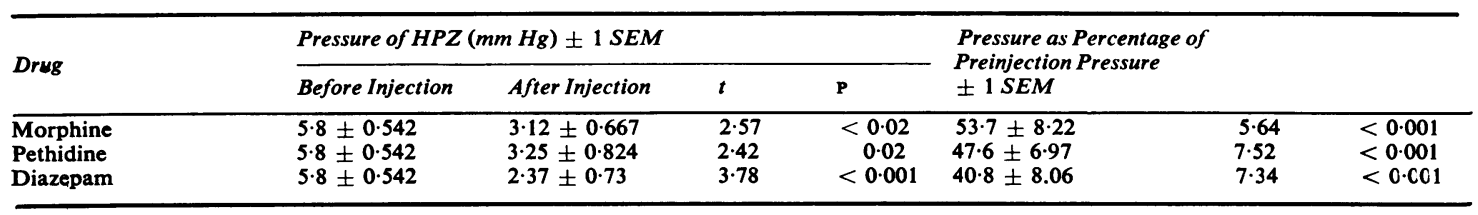

Table II Effect of drugs on HPZ pressures in Rhesus monkeys 


\section{Discussion}

As early as 1926 Robins and Jankelson started the wave of interest in 'gastrooesophageal relaxation'. In 1960, Bettarello, Tuttle, and Grossman showed that the intraluminal pressure of the lower oesophagus was reduced by atropine and increased by bethanecol. These authors also claimed that atropine significantly increased gastrooesophageal reflux and bethanecol significantly reduced its incidence. The effects of atropine on the high pressure zone were later confirmed by Skinner and Camp in 1968, but they were unable to demonstrate any convincing effect on the reflux status. Metoclopramide has been shown to have a strong tonic effect on the high pressure zone (Heitmann and Möller, 1970) while smoking (Dennish and Castell, 1971) and caffeine (Dennish and Castell, 1972) have been shown to lower intraluminal pressures.

Giles, Mason, Humphries, and Clark (1969) and Castell and Harris (1970) showed that gastrin had a tonic effect on the lower oesophageal high pressure zone. Following on this work, it was shown that secretin (Cohen and Lipshutz, 1971), glucagon (Jennewein, Waldeck, Siewert, Weiser, and Thimm, 1973), and the C-terminal octapeptide of cholecystokinin (Resin, Stern, Sturdevant, and Isenburg, 1973) all have a depressant effect on the high pressure zone. In 1972 Moossa, Cooley, and Skinner demonstrated that continuous intravenous infusion of gastrin or secretin only had a transient, nonspecific effect on the lower oesophagus and did not alter the reflux status of Rhesus monkeys. They failed to elicit any effect of cholecystokinin on either the manometric or the reflux status of these animals. More recently, the prostaglandins have all been shown to have some effect on the pressures in the high pressure zone (Goyal and Rattan, 1973; Dilawari, Newman, Poleo, and Misiewicz, 1973). The practical value of all this is still not clear since the reported changes in pressures in the high pressure zone are often only transient and have not been demonstrated to correlate with any change in reflux status of the subjects.

Our results show that the pressure changes induced by the three drugs on the lower oesophagus significantly increase the probability of reflux in an individual. If the subject is known to reflux spontaneously, the severity of reflux as judged by standard acid reflux tests will be increased. This has a direct relevance in the preparation of patients for surgery when gastrooesophageal reflux and pulmonary aspiration may be a problem in the pre-and postoperative phases.

One question which arises is whether our findings are really due to drug action or not. From examina- tion of our experimental method it will be noted that all control tests in both man and monkey were performed first. Since acid was placed in the stomach as part of the reflux tests it could be argued that the subsequent fall in pressure in the high pressure zone was due to inhibition of endogenous gastrin secretion rather than the influence of the drug subsequently administered. This is not true for three reasons. First there was a marked difference in the two sets of acid reflux tests which were of necessity both performed after the administration of acid. Secondly, oesophageal manometry performed before and after the addition of acid to the fasting stomach does not show any alteration in pressures in the high pressure zone (Moossa and Skinner, unpublished data). Thirdly, physiological changes in gastrin levels have an insignificant role in the function of the high pressure zone (Grossman, 1973; Frank, Walker, and Fordtran, 1973).

No control injections were administered to our patients, but in an essentially similar experiment with atropine Skinner and Camp (1968) administered $1 \mathrm{ml}$ saline intravenously to eight volunteers. No significant change in pressure in the high pressure zone or reflux was noted. This was taken to show that neither an intravenous saline injection nor the introduction of acid into the stomach influenced the results.

All three drugs used in our experiments are currently extensively employed in clinical practice either as a form of sedation or as premedicating and postoperative analgesic drugs. Great caution must be exhibited in the administration of these drugs in doses sufficient to cause drowsiness in subjects who will not be under constant skilled supervision. The increased risk of regurgitation and pulmonary aspiration, especially in patients with known gastrooesophageal reflux, should be stressed to nursing staff having the care of these patients.

\section{References}

Bettarello, A., Tuttle, S. G., and Grossman, M. I. (1960). Effect of Autonomic drugs on gastrooesophageal reflux. Gastroenterology, 39, 340-346.

Castell, D. O. and Harris, L. D. (1970). Hormonal control of gastroesophageal sphincter strength. New. Engl.J.Med., 282, 886-889.

Cohen, S., and Lipshutz, W. (1971). Hormonal regulation of human lower esophageal sphincter competence, interaction of gastrin and secretin. J. clin. Invest., 50, 449-454.

Dennish, G. W., and Castell, D. O. (1971). Inhibitory effect of smoking on the lower esophageal sphincter. New. Engl. J. Med., 284, 1136-1137.

Dennish, G. W. and Castell, D. O. (1972). Caffeine and the lower esophageal sphincter. Amer.J. Dig. Dis. 17, 993-996.

Dilawari, J. B., Newman, A., Poleo, J., and Misiewicz, J. J. (1973). The effect of prostaglandins and of anti-inflammatory drugs on the oesophagus and the cardiac sphincter in man. (Abstr.) Gut, 14, 822.

Frank, S. A., Walker, C. O., and Fordtran, J. S. (1973). The effect of continuous pentagastrin infusion (PG) on lower esophageal sphincter pressure (LES) (Abstr.) Gastroenterology, 64, 728. 
Giles, G. R., Mason, M. C., Humphries, C., and Clark, C. G. (1969). Action of gastrin on the lower oesophageal sphincter in man. Gut, 10, 730-734.

Glanville, J. N., and Walls, W. D. (1972). Effect of intravenous metaclopramide on gastrooesophageal reflux. Gut, 13, 31. 32.

Goyal, R. K., and Rattan, S. (1973). Mechanism of the lower esophageal sphincter relaxation, action of prostaglandin $E$, and theophylline. J. clin. Invest., 52, 337-341.

Grossman, M. I. (1973). What is physiological? (Letter). Gastroenterology, 65, 994.

Heitmann, P., and Möller, N. (1970). The effect of metaclopramide on the gastrooesophageal junction zone and the distal esophagus in man. Scand. J. Gastroent., 5, 621-625.

Jennewein, H. M., Waldeck, F., Siewert, R., Weiser, F., and Thimm, R. (1973). The interaction of glucagon and pentagastrin on the lower oesphageal sphincter in man and dog. Gut, 14, 861-864.
Moossa, A. R., Cooley, G. R., and Skinner, D. B. (1973). Intraluminal and Intraperitoneal pressures at the cardia: effect of hormones and surgical intervention. Surg. Forum, 24, 370-372.

Resin, H., Stern, D. H., Sturdevant, R. A. L., and Isenberg, J. I. (1973). Effect of the C-terminal octapeptide of cholecystokinin on lower esophageal sphincter pressure in man. Gastroenterology, 64, 946-949.

Robins, S. A., and Jankelson, L. R. (1926). Cardioesophageal relaxation. J. Amer. med. Ass. 87, 1961-1964.

Skinner, D. B., and Camp, T. F., Jr. (1968). Relation of esophageal reflux to lower esophageal sphincter pressures decreased by atropine. Gastroenterology, 54, 543-551.

Thurer, R. L., DeMeester, T. R., and Johnson, L. F. (1974). The distal esophageal sphincter and its relationship to gastroesophageal reflux. J. surg. Res., 16, 418-423.

Winans, C. S., and Harris, L. D. (1967). Quantitation of lower esophageal sphincter competence. Gastroenterology, 52,773-778.

\section{The April 1975 Issue}

\section{THE APRIL 1975 ISSUE CONTAINS THE FOLLOWING PAPERS}

Oral manifestations of Crohn's disease M. K. BASU, P. ASQUITH, R. A. THOMPSON, AND W. T. COOKE

Estimation of carcinoembryonic antigen in ulcerative colitis with special reference to malignant change J. B. DILAWARI, J. E. LENNARD-JONES, A. M. MACKAY, JEAN K. RITCHIE, AND H. G. STURZAKER

Ileal function in patients with untreated adult coeliac disease D. B. A. SILK, PARVEEN J. KUMAR, JOAN P. W. WEBB, ANNETTE E. LANE, M. L. CLARK, AND A. M. DAWSON

A controlled, randomized trial of highly selective vagotomy versus selective vagotomy and pyloroplasty in the treatment of duodenal ulcer $o$. KRONBORG AND P. MADSEN

The effect of intravenous infusions of prostaglandins $E_{2}$ and $F_{2 \alpha}$ on human gastric function A. NEWMAN, J. PRADO p. de MORAES-FILHO, D. PHILIPPAKOS, AND J. J. MISIEWICZ

Electrical potential difference, sodium absorption and potassium secretion by the human rectum during carbenoxolone therapy A. M. TOMKINS AND C. J. EDMONDS
Pancreatitis after renal transplantation P. CORRODI, M. KNOBLAUCH, U. BINSWANGER, E. SCHÖLZEL, AND F. LARGIADÈR

A study of lymph nodes draining colorectal cancer using a two-stage inhibition of leucocyte migration technique P. J. GUILLOU, T. G. BRENNAN, AND G. R. GILES

\section{Symposium on colonic function}

Electrophysiology of the colon E. E. DANIEL

Pharmacology of colonic muscle ALAN BENNETT

Colonic motility J. J. MISIEWICZ

Electrical potential difference of colonic mucosa C. J. EDMONDS

The normal colonic bacterial flora M. J. HILL AND B. S. DRASAR

Absorption and secretion by the colon JOHN H. CUMMINGS

Notes and activities

Copies are still available and may be obtained from the PUBLISHING MANAGER, BRITISH MEDICAL ASSOCIATION, TAVISTOCK SQUARE, LONDON, WC1 $9 \mathrm{JR}$, price $£ 2 \cdot 00$, including postage 